\title{
Multilocation Straw Removal Effects on Sugarcane Yield in South-Central Brazil
}

\author{
João Luís Nunes Carvalho ${ }^{1}$ Lauren Maine Santos Menandro ${ }^{1,2}$. Sérgio Gustavo Quassi de Castro ${ }^{1}$. \\ Maurício Roberto Cherubin ${ }^{3}$ - Ricardo de Oliveira Bordonal ${ }^{1}$ - Leandro Carneiro Barbosa ${ }^{1,4}$. \\ Leandro Carolino Gonzaga ${ }^{1,2}$. Sarah Tenelli ${ }^{1,2}$. Henrique Coutinho Junqueira Franco ${ }^{1}$. Oriel Tiago Kolln ${ }^{1}$. \\ Guilherme Adalberto Ferreira Castioni ${ }^{1}$
}

Published online: 12 July 2019

(C) The Author(s) 2019

\begin{abstract}
Sugarcane straw is a crop residue that has a dual purpose and can be maintained on the fields or used to produce bioenergy. The straw retention in the field provides multiple ecosystem services, and the complex interactions between straw and yield responses are hard to predict by local studies. The aim of this study was to investigate the straw removal effects on sugarcane yield in southcentral Brazil. To achieve the objective, a set of 21 field studies was conducted in contrasting edaphoclimatic conditions. In addition, data of seven studies from the literature were included to build a more robust dataset. Since straw removal treatments were not homogeneous in all experiments, they were grouped as follows: NR, no removal (baseline treatment); LR, low removal; MR, moderate removal; and TR, total removal. To facilitate the data analysis, the experiments were gathered in four macroregions: southern Goiás, western São Paulo, central-eastern São Paulo, and northeastern São Paulo. The site location was the most effective individual factor to explain the straw removal effects on sugarcane yields. Compared with NR treatment, the average yield losses induced by LR, MR, and TR were 2,10 , and $13 \mathrm{Mg} \mathrm{ha}^{-1}$ in southern Goiás and 2, 4, and $6 \mathrm{Mg}^{-1}$ in western São Paulo states, respectively. In other regions, no clear pattern was observed, and only site-specific effects were observed. Straw removal affected sugarcane yields in all soil types, but higher responses were observed under best conditions for sugarcane growth (i.e., clayey soils in southern Goiás). Our findings indicated harvesting season has a relevant role on determining yield responses to straw removal and younger ratoons are more responsive to straw removal. Conclusions from this study suggest straw removal recommendations cannot be designed based on isolated factors but require holistic and integrated knowledge to ensure that the straw amount left on field is enough to sustain multiple soil ecosystem services and crop yields.
\end{abstract}

Keywords Crop residues · Saccharum spp. · Stalk yield · Bioenergy production

João Luís Nunes Carvalho

joao.carvalho@ctbe.cnpem.br

1 Brazilian Biorenewables National Laboratory (LNBR) - Brazilian Center of Energy and Material Research (CNPEM), Giuseppe Maximo Scolfaro Street, 10000, Campinas, SP 13083-100, Brazil

2 Interdisciplinary $\mathrm{PhD}$. Program in Bioenergy, University of Campinas (UNICAMP), Monteiro Lobato Street, 80, Cidade Universitária, Campinas, SP 13083-862, Brazil

3 Department of Soil Science, College of Agriculture "Luiz de Queiroz", University of São Paulo, C.P. 09, Piracicaba, SP 13418-900, Brazil

4 Faculty of Agricultural Engineering, University of Campinas FEAGRI/UNICAMP, Cândido Rondon, Avenue, 501. Barão Geraldo, Campinas, SP 13083-875, Brazil

\section{Introduction}

Brazil is currently the world's largest producer of sugarcane, responsible for $40 \%$ of global production [1]. Based on sugarcane, Brazil became one of the major players of the bioenergy sector, being the second world's largest producer of bioethanol (32 billion L) [2] and has the largest fleet of flex-fuel vehicles ( $\sim 30$ million) [3]. Despite this leadership in the sugarcane sector, the country has experienced alarming stagnation of crop yields in the past 15 years, averaging $75 \mathrm{Mg} \mathrm{ha}^{-1}$ of stalks [2], much lower than the crop potential yield $\left(\sim 200 \mathrm{Mg} \mathrm{ha}^{-1}\right)$ for Brazilian conditions [4]. The main reasons for low crop yields include soil degradation induced by intensive machinery traffic, crop damage associated with mechanical harvesting, pest proliferation, aging of sugarcane fields, climate constraints, and low sector's capacity of investments [4-6]. 
Growing demands of bioenergy boosted by international commitment and sectorial policy (e.g., RenovaBio [7]) to mitigate global climate change have raised the interest of Brazilian industry for increasing crop yield and using the sugarcane crop residues (i.e., straw) as feedstock to produce bioelectricity or cellulosic ethanol [8]. The large-scale availability of sugarcane straw in Brazil, particularly in south-central region, which concentrates $92 \%$ of national sugarcane production [9], offers an attractive opportunity to enhance competitiveness of the biofuel industries [10]. Nevertheless, the maintenance of straw in the field underpins and modulates key soil processes, functions, and ecosystem services [11]. Accordingly, benefits of straw maintenance on soil quality can both directly and indirectly affect sugarcane growth and yield $[12,13]$. Therefore, this new scenario of straw removal may result in even lower sugarcane yield, threatening the sustainability of bioenergy production.

In the past few years, the straw removal effects on sugarcane yield have been investigated in different locations in south-central Brazil $[5,12,14,15]$. However, there is no consensus about the sugarcane yield responses to straw removal. Since the straw removal can increase, decrease, or have no net impacts on crop yields, the understanding of straw removal effects on sugarcane yield is still unclear, thus hindering the adoption of sustainable straw management and strategic decision-making for promoting bioenergy production on a regional or even national scale.

Recognizing that several public and private groups were expressing interest in the use of straw from industry purposes, the SUCRE (Sugarcane Renewable Electricity) project was initiated in 2015, funded by the Global Environment Facility (GEF) and managed by the United Nations Development Program (UNDP), with the primary goal of providing scientific-based data to the sugarcane sector that support the decision-making on straw management, establishing a rational plan to remove straw from the field without compromising soil health and sugarcane yield.

Based on this scenario, we hypothesized that straw has relevant roles in sustaining soil health and plant growth, and therefore indiscriminate straw removal rates result in substantial losses of sugarcane yield. To test this hypothesis, the SUCRE project was conducted, aiming to investigate the effects of straw removal on sugarcane yield in south-central Brazil. To achieve the objective, a set of 21 field studies was conducted to quantify crop yield response to straw removal management in contrasting conditions of soil and climate in south-central Brazil. The focus was also to synthesize the literature data from similar experiments conducted in the same regions to increase the number of observations and provide more robust and reliable information on a regional scale.

\section{Material and Methods}

\section{Description of the Study Areas}

Twenty-one field studies were conducted in the SUCRE project to quantify the impacts of sugarcane straw removal on subsequent stalk yields. The experimental sites were strategically chosen to represent diverse edaphoclimatic conditions in the most intensively cultivated sugarcane regions (São Paulo state) and those of recent expansion (Goiás state) in south-central Brazil (Fig. 1). São Paulo and Goiás states are the two largest sugarcane producers of Brazil, accounting for $54 \%$ and $11 \%$ of national production, respectively [9]. In addition to the 21 trials supported by the SUCRE project, data from other seven field studies available in the literature were synthesized to build a more robust dataset for better understanding the straw removal effects on sugarcane yields, totaling 28 field studies conducted on clayey, loamy, and sandy soils.

The experiments were grouped into four sugarcaneproducing macroregions (southern Goiás, western São Paulo, central-eastern São Paulo, and northeastern São Paulo) to facilitate the data analysis (Fig. 1). These macroregions were grouped based on geographic locations and predominant weather conditions. In general, southern Goiás presents a climate classified as B1wA'a', which is humid with moderate water deficit in the winter, and high temperature and precipitation in the summer [16]. All experimental sites in this region present a recent history of sugarcane cultivation ( $\leq 12$ years). In western São Paulo, the climate is C1wA' $a$ ', sub-humid with moderate water surplus in the summer and with high water deficit in the winter and the soils are predominantly sandy. In the central-eastern region of São Paulo, the climate is classified as C1wB'4a', sub-humid climate with moderate water surplus in the summer, cooler temperatures in the winter, and is represented by a wide range of soil types. In northeastern São Paulo, the climate is C2wB' $4 a$ ', which is sub-humid mesothermic with moderate water deficit in the winter and the soils are predominantly clayey. The last two macroregions are the most traditional locations of sugarcane cultivation in south-central Brazil. Descriptions of each experimental site (e.g., municipalities, soil classification, texture, altitude, precipitation, and temperature) and details about specific climate conditions, sugarcane varieties, harvesting seasons, and the evaluated ratoon cycles are shown in Table 1. The characterization of the soil chemical and physical attributes was performed at the beginning of each field experiment (Table 2).

\section{Experimental Design and Treatments}

All field studies were established in a randomized block design with four repetitions, considering four treatments for some trials and three treatments for the remainder. 


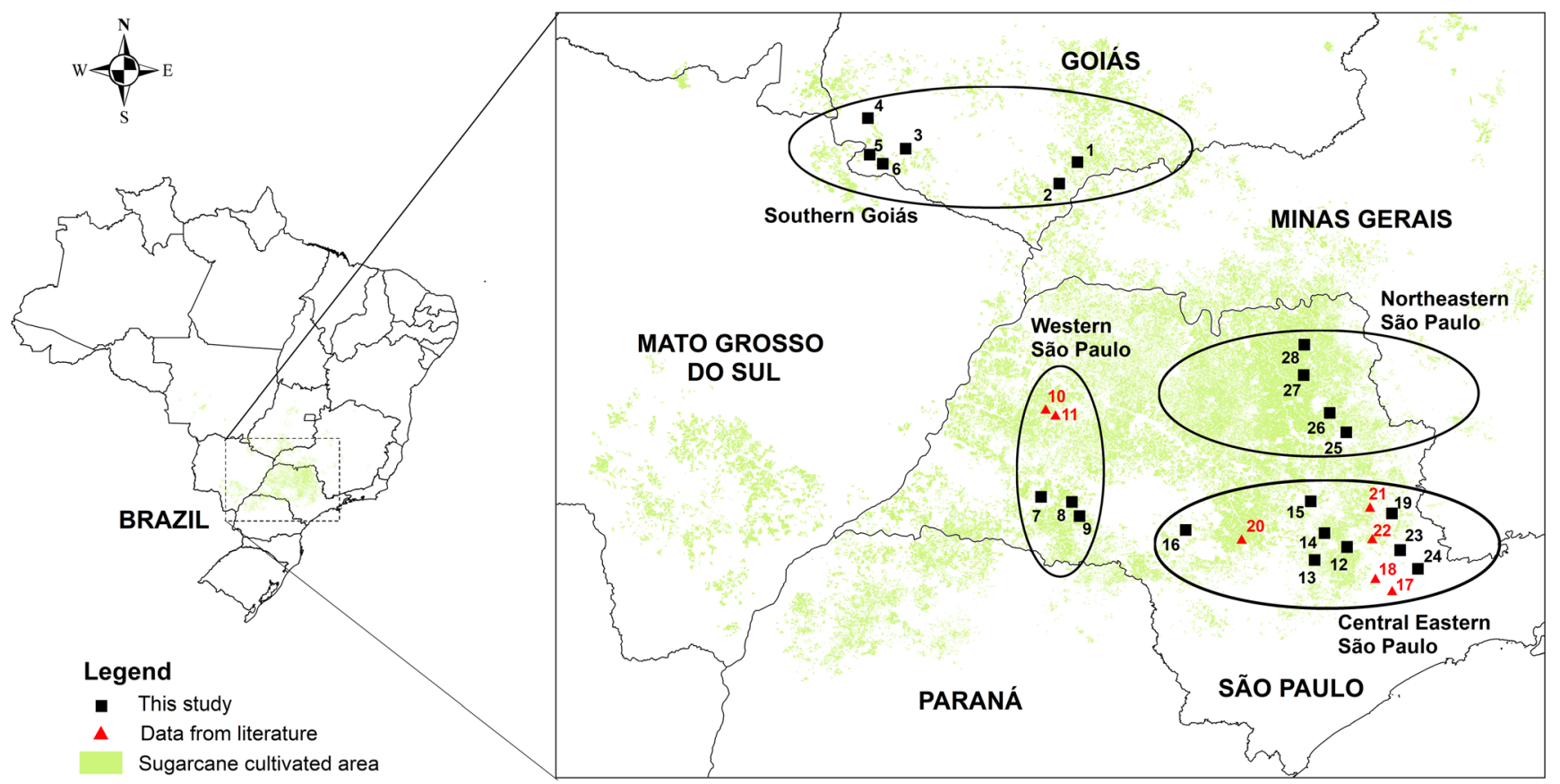

Fig. 1 Geographic locations of the sites included in this study (SUCRE's experiments) and those obtained from the literature review. Field studies were grouped into four macroregions as follows: Southern Goiás, western São Paulo, central-eastern São Paulo, and northeastern São Paulo. Black squares denote the sites where SUCRE's experiments were conducted and red triangles show the sites where data were compiled from the published literature. Sugarcane cultivation map was processed according to the updated data from the Canasat's project (www.dsr.inpe.br/laf/ canasat/)
Dimensions of each individual plot were $10 \mathrm{~m}$ long by $12 \mathrm{~m}$ wide, comprising eight sugarcane rows at $1.5-\mathrm{m}$ spacing. All plots received an annual ratoon fertilization of $120 \mathrm{~kg} \mathrm{ha}^{-1}$ nitrogen (ammonium nitrate) and $120 \mathrm{~kg} \mathrm{ha}^{-1}$ potassium (potassium chloride). During the experimental period, organic amendments such as vinasse and filter cake were not applied in the fields. Applications of fungicides, insecticides, and herbicides were uniform in all plots and conducted according to the management strategies established by each sugarcane mill.

The amount of straw on the soil surface after sugarcane harvesting in each field experiment was quantified annually through a metallic frame $\left(0.25 \mathrm{~m}^{2}\right)$ randomly thrown in the field ten times. Straw moisture measurement was performed directly in the field using the sensor AL-104 Agrologic ${ }^{\circledR}$ with E-831 Electrode coupled. After straw quantification (on dry basis), four straw removal rates were established in the first group of trials: total (TR, $0 \mathrm{Mg} \mathrm{ha}^{-1}$ ), high (HR, $5 \mathrm{Mg} \mathrm{ha}^{-1}$ ), low (LR, $10 \mathrm{Mg} \mathrm{ha}^{-1}$ ), and no removal (NR, $15 \mathrm{Mg} \mathrm{ha}^{-1}$ ). For another experimental group, the removal rates were established after sugarcane harvesting based on the amount of straw produced in each year, comprising of three treatments: $0 \%, 50 \%$, and $100 \%$ straw removal. More details about the methodology for adjustment of the correct amount of dry straw within each experimental group are available in Bordonal et al. [6] and Castioni et al.
[22]. The same procedures were repeated annually after the harvesting of subsequent ratoons to evaluate the cumulative effects of straw removal on sugarcane yields. Since different experimental groups correspond to distinct amounts of straw on the soil surface, we grouped the treatments in this study for analysis purposes as follows: NR (all straw left on soil surface), LR (from 25 to $33 \%$ removal), MR (from 50 to $66 \%$ removal), and TR (bare soil).

\section{Sampling and Measurements of Sugarcane Stalk Yields}

The evaluated period (e.g., evaluated ratoon cycles) for which sugarcane was harvested at various locations ranged from one to five years (Table 1). The sugarcane stalk yield was measured after approximately 360 days of cultivation in all experimental sites; however, the harvesting seasons varied according to the crop season of each location in the south-central region: early (March-May), middle (June-August), and late (September-November) (Table 1).

At the harvest period, each plot was harvested by means of a mechanical harvester and stalk yields (expressed in $\mathrm{Mg} \mathrm{ha}^{-1}$ ) were computed for the four central rows through an instrumented truck equipped with a loading cell (used exclusively for experiments). 


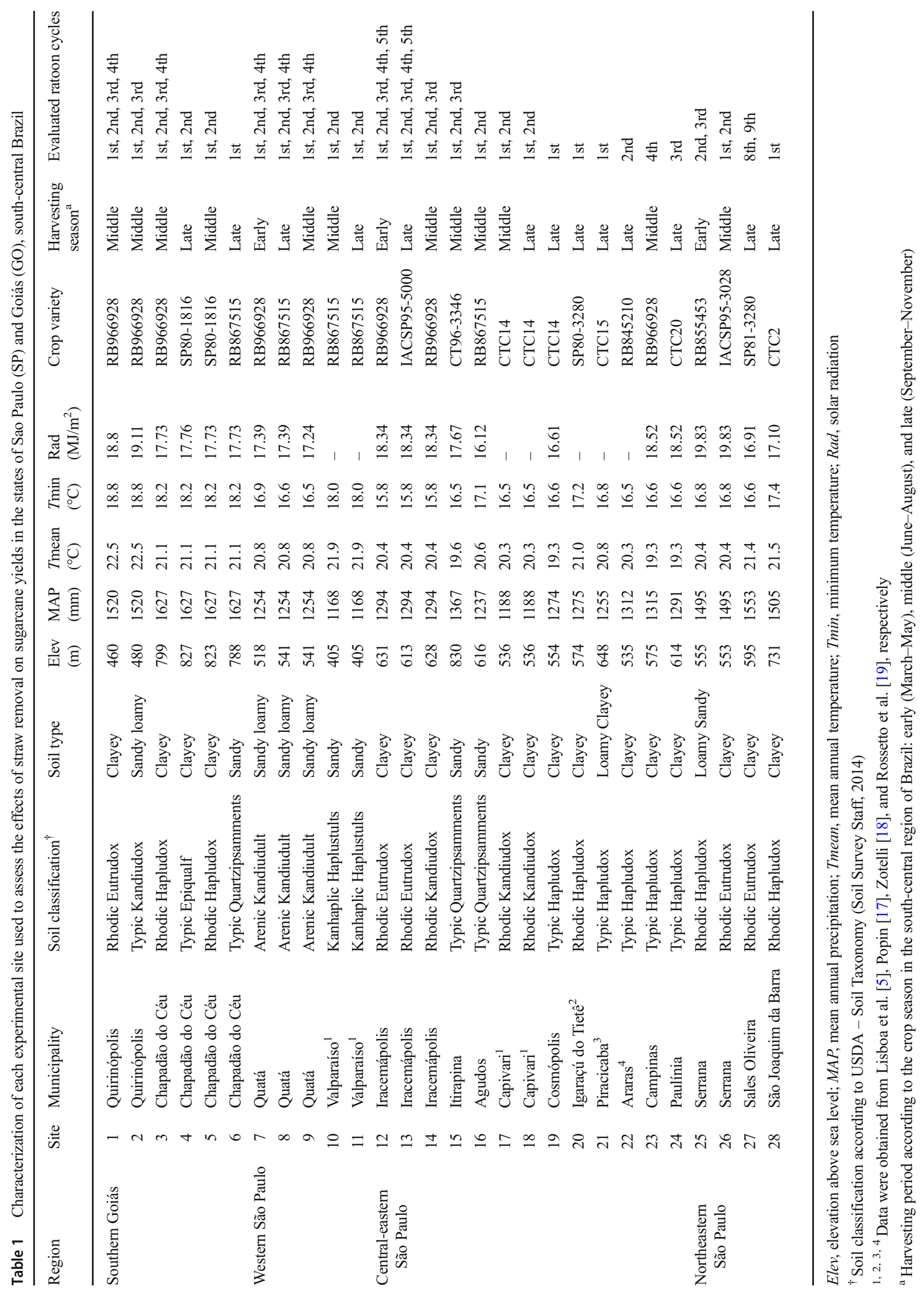


Table 2 Characterization of soil chemical and physical attributes at the beginning of the experimental period. Data represent $0-40$-cm soil layer

\begin{tabular}{|c|c|c|c|c|c|c|c|c|c|c|c|}
\hline Region & Site & $\begin{array}{l}\mathrm{pH}^{\mathrm{a}} \\
\mathrm{CaCl}_{2}\end{array}$ & $\begin{array}{l}\mathrm{C} \\
\%\end{array}$ & $\begin{array}{l}\mathrm{P} \\
\mathrm{mg} \mathrm{dm}\end{array}$ & $\begin{array}{l}\mathrm{K} \\
\mathrm{mmo}\end{array}$ & $\begin{array}{c}\mathrm{Ca} \\
\mathrm{n}^{-3}\end{array}$ & $\mathrm{Mg}$ & $\begin{array}{l}\text { BS } \\
\%\end{array}$ & $\begin{array}{l}\text { Sand } \\
\mathrm{g} \mathrm{kg}^{\mathrm{b}}\end{array}$ & Clay & Silt \\
\hline \multirow[t]{6}{*}{ Southern Goiás } & 1 & 5.5 & 1.79 & 8 & 4.0 & 40 & 12 & 71 & 247 & 563 & 190 \\
\hline & 2 & 5.9 & 1.07 & 5 & 0.6 & 17 & 8 & 61 & 749 & 226 & 25 \\
\hline & 3 & 5.0 & 2.09 & 11 & 2.0 & 26 & 9 & 53 & 209 & 639 & 152 \\
\hline & 4 & 5.6 & 2.66 & 52 & 0.8 & 33 & 14 & 68 & 424 & 536 & 40 \\
\hline & 5 & 6.2 & 1.8 & 29 & 1.9 & 49 & 14 & 76 & 335 & 490 & 175 \\
\hline & 6 & 5.3 & 1.21 & 12 & 0.7 & 23 & 5 & 60 & 916 & 66 & 18 \\
\hline \multirow[t]{5}{*}{ Western São Paulo } & 7 & 5.4 & 0.53 & 7 & 1.0 & 34 & 3 & 79 & 825 & 111 & 64 \\
\hline & 8 & 5.0 & 0.45 & 9 & 1.0 & 18 & 7 & 61 & 807 & 72 & 122 \\
\hline & 9 & 4.8 & 0.37 & 16 & 0.3 & 12 & 4 & 49 & 829 & 112 & 59 \\
\hline & $10^{\#}$ & 4.8 & 0.55 & 15 & 2.7 & 6 & 2 & 38 & 863 & 115 & 22 \\
\hline & $11^{\#}$ & 4.8 & 0.55 & 15 & 2.7 & 6 & 2 & 38 & 863 & 115 & 22 \\
\hline \multirow[t]{13}{*}{ Central-eastern São Paulo } & 12 & 5.3 & 2.35 & 66 & 21.0 & 46 & 18 & 82 & 255 & 577 & 168 \\
\hline & 13 & 5.2 & 2.13 & 46 & 10.6 & 54 & 29 & 65 & 229 & 602 & 168 \\
\hline & 14 & 4.4 & 2.04 & 52 & 7.3 & 19 & 8 & 40 & 140 & 666 & 194 \\
\hline & 15 & 5.5 & 0.76 & 38 & 1.5 & 17 & 9 & 54 & 923 & 54 & 22 \\
\hline & 16 & 4.9 & 0.66 & 8 & 1.2 & 19 & 7 & 55 & 870 & 100 & 31 \\
\hline & $17^{\S}$ & 4.8 & 1.60 & 25 & 5.9 & 19 & 5 & 53 & 603 & 330 & 65 \\
\hline & $18^{\S}$ & 4.8 & 1.60 & 25 & 5.9 & 19 & 5 & 53 & 603 & 330 & 65 \\
\hline & 19 & 5.8 & 1.63 & 8 & 8 & 46 & 22 & 44 & 445 & 415 & 140 \\
\hline & 20 & 5.2 & 1.89 & 22 & 4 & 34 & 15 & 66 & 147 & $853^{*}$ & - \\
\hline & 21 & 4.5 & 1.2 & 19 & - & - & - & 23 & - & 285 & - \\
\hline & 22 & 5.0 & 2.2 & 24 & 3.6 & 46 & 23 & 59 & - & 770 & - \\
\hline & 23 & 4.85 & 1.3 & 10 & 0.6 & 27 & 8 & 50 & 290 & 650 & 61 \\
\hline & 24 & 4.57 & 1.5 & 19 & 3.4 & 21 & 7 & 40 & 290 & 650 & 7 \\
\hline \multirow[t]{4}{*}{ Northeastern São Paulo } & 25 & 5.57 & 1.60 & 29 & 2.3 & 39 & 8 & 69 & 346 & 490 & 165 \\
\hline & 26 & 5.97 & 2.22 & 116 & 9.6 & 82 & 12 & 80 & 282 & 484 & 234 \\
\hline & 27 & 5.67 & 1.50 & 7 & 1.2 & 32 & 9 & 63 & 68 & 713 & 220 \\
\hline & 28 & 5.23 & 2.58 & 30 & 2.8 & 26 & 12 & 49 & 288 & 584 & 128 \\
\hline
\end{tabular}

${ }^{\mathrm{a}}$ Soil chemical analyses were performed according to van Raij et al. [20]. ${ }^{\mathrm{b}}$ Soil particle-size analysis according to Blake and Hartge [21]; BS, base saturation. ${ }^{\#}$ and ${ }^{\S}$ The same experimental areas differing only in harvesting season. *Content of clay + silt

\section{Literature Search}

We performed a literature review of studies reporting data on the influence of straw removal on sugarcane stalk yields (on wet basis). The keywords (in English or Portuguese) "sugarcane", "straw", "trash", "crop residues", "stalk yield", "sugarcane yield", "biomass production", and "Brazil" were used as search terms in the main databases (Web of Science, Scopus, Science Direct, Scielo, and Google Scholar). To filter the results, we used additional criteria, such as (i) only studies conducted in south-central Brazil; (ii) only studies that evaluated at least three rates of straw removal; (iii) only studies performed in field conditions; and (iv) only studies published in the last decade, which represents the production of sugarcane under mechanized harvesting without burning. After filtering, seven studies were selected, encompassing a wide range of locations in the São Paulo state (Fig. 1).

\section{Data Analysis}

The normality of data was confirmed by the Shapiro-Wilk test $(p>0.05)$, and data transformations were not required to meet the assumptions of the analysis of variance (ANOVA). Then, data were subjected to ANOVA to test the effects of straw removal rates on sugarcane yields in each location and ratoon cycle. When statistically significant $(p<0.05)$, the average values of sugarcane yields were compared according to Tukey's test $(p<0.05)$. All statistical analyses were performed using the R software [23]. Additionally, regional averages of sugarcane yield changes induced by straw removal were 
calculated by grouping the sites located in southern Goiás, western São Paulo, central-eastern São Paulo, and northeastern São Paulo. Changes in sugarcane stalk yields induced by straw removal rates for each location and ratoon cycle were computed according to Eq. 1:

Sugarcane yield changes $=$ Yield $_{i}-$ Yield $_{\mathrm{NR}}$

where, Sugarcane yield changes are expressed in $\mathrm{Mg} \mathrm{ha}^{-1}$ year $^{-1}$, Yield $_{i}$ is the sugarcane yield $\left(\mathrm{Mg} \mathrm{ha}^{-1}\right)$ achieved in the $i$ straw removal treatments (i.e., LR, MR, and TR), Yield $\mathrm{NR}_{\mathrm{N}}$ is the sugarcane yield $\left(\mathrm{Mg} \mathrm{ha}^{-1}\right)$ achieved in the NR (i.e., baseline treatment).

Linear regression analyses were performed between the amounts of straw left on the soil surface for each straw removal scenario to estimate the Sugarcane Yield Change (SYC) index. The SYC index indicates the impact of each megagram of straw removed from the field on sugarcane yield (i.e., expressed in terms of $\mathrm{Mg}$ of stalk per $\mathrm{Mg}^{-1}$ of straw removed) and represents the " $\mathrm{b}$ " of the linear equation $(y=a+b x)$. When the linear regression was significant $(p<0.05)$ for each site year, the values of the SYC index were included in this study to estimate the implication of straw removal on sugarcane stalk yield.

\section{Results}

\section{Effects of Straw Removal Rates on Sugarcane Yield}

The results of our 67 site-year database revealed that straw removal affected sugarcane yields in all evaluated regions (Fig. 2), although the effects were clearly site-specific and dependent on the crop cycles. Overall, straw removal effects on sugarcane yields were more significant in southern Goiás and western São Paulo (Table 3), which, the annual losses of sugarcane yield induced by LR, MR, and TR averaged 2, 10, and $13 \mathrm{Mg} \mathrm{ha}^{-1}$ and 2, 4, and $6 \mathrm{Mg} \mathrm{ha}^{-1}$, respectively (Fig. 2a). Although higher absolute yield losses were observed in southern Goiás compared with western São Paulo, the relative losses (in percentage) were similar for both regions (Fig. 2b). This is associated with the higher sugarcane yields observed in the sites in southern Goiás (average of $129 \mathrm{Mg} \mathrm{ha}^{-1}$; Table 3) in relation to western São Paulo (average of $71 \mathrm{Mg} \mathrm{ha}^{-1}$ ).

In southern Goiás, straw removal resulted in significant changes $(p<0.05)$ in sugarcane yields in 13 out of 16 evaluated site-years (Table 3). On average, straw removal reduced sugarcane yield in four sites, with a maximum yield loss (40 $\mathrm{Mg} \mathrm{ha}^{-1}$ ) observed on site 1 in the 1 st ratoon cycle (Fig. 3). In sites 4 (hydromorphic clayey soil) and 5 (clayey soil under regular irrigation), opposite responses were observed especially in the 1st ratoon cycle, in which higher yields were associated with TR treatment. Heterogeneous yield responses were observed along the years in sites 3, 4, and 5, indicating a direct effect of weather conditions on crop yield response to straw removal in a specific year. For example, straw removal was detrimental to sugarcane yield in the 1 st, 2 nd, and 4 th ratoon cycles for site 3 , while the same pattern was not observed in the 3rd ratoon cycle. Likewise, distinct yield responses were found in the 1 st and 2 nd ratoons for sites 4 and 5. It is important to mention that in this region, LR treatment did not differ from NR and all significant impacts of straw removal were observed in MR and TR (Fig. 3).

Straw removal reduced sugarcane yield in most sites of western São Paulo (Table 3 and Fig. 4). In a similar way to that observed in southern Goiás, the highest effects of straw removal on sugarcane yield were observed in younger ratoons. Under similar soil and climate conditions, sites 7,8 , and 9 presented different yield responses according to harvesting seasons (Table 1 and Table 2). Significant yield responses to straw

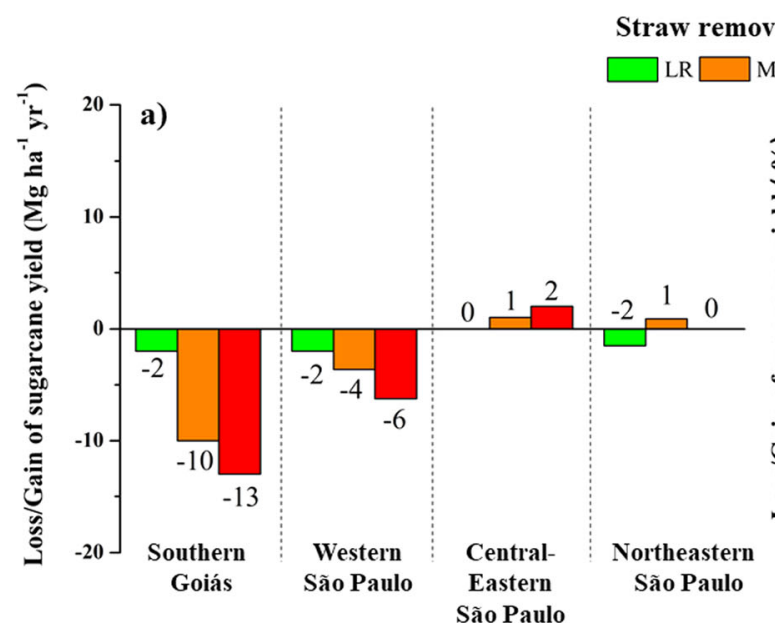

Fig. 2 Regional sugarcane yield loss/gain, in $\mathrm{Mg} \mathrm{ha}^{-1}$ year $^{-1}$ (a) and percentage (b), induced by straw removal in relation to no removal treatment (baseline). Data represent the average of all studies in each

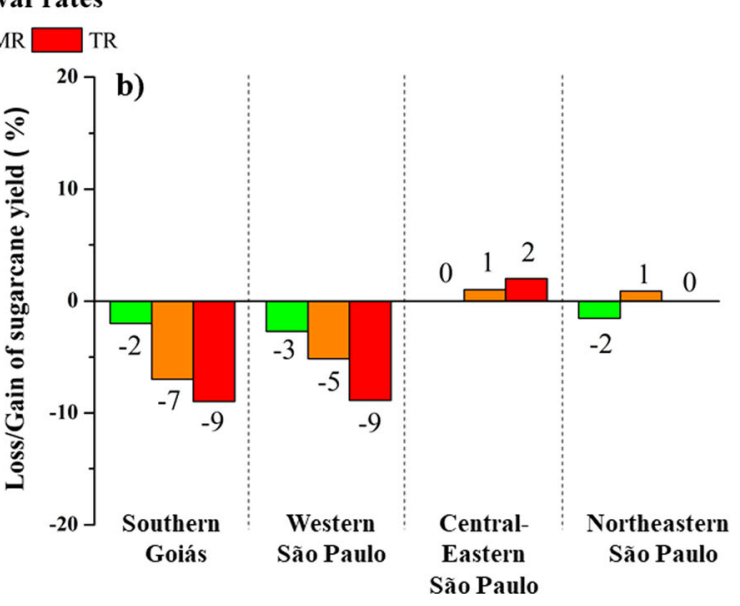

macroregion. Negative and positive values indicate annual loss and gain of sugarcane yield, respectively. LR, MR, and TR denote low, moderate, and total removal of sugarcane straw 
Table 3 Mean sugarcane stalk yield $\left(\mathrm{Mg} \mathrm{ha}^{-1}\right)$ induced by straw removal on each sugarcane ratoon cycle in southern Goiás, western São
Paulo, central-eastern São Paulo, and northeastern São Paulo. Data represent the average of four replicates

\begin{tabular}{|c|c|c|c|c|c|c|c|c|c|c|}
\hline \multirow[t]{2}{*}{ Region } & \multirow[t]{2}{*}{ Site } & \multirow[t]{2}{*}{ Evaluation period } & \multicolumn{8}{|c|}{ Straw removal } \\
\hline & & & \multicolumn{2}{|l|}{ NR } & \multicolumn{2}{|l|}{ LR } & \multicolumn{2}{|l|}{ MR } & \multicolumn{2}{|l|}{ TR } \\
\hline & & & $\mathrm{Mg}$ & & & & & & & \\
\hline \multirow[t]{16}{*}{ Southern Goiás } & 1 & 1st ratoon & 178 & $\mathrm{a}$ & - & $£$ & 138 & $\mathrm{~b}$ & 138 & $\mathrm{~b}$ \\
\hline & & 2 nd ratoon & 145 & $\mathrm{a}$ & - & & 127 & $\mathrm{~b}$ & 123 & $\mathrm{~b}$ \\
\hline & & 3rd ratoon & 159 & $\mathrm{a}$ & - & & 136 & $\mathrm{~b}$ & 121 & $\mathrm{~b}$ \\
\hline & & 4 th ratoon & 85 & $\mathrm{a}$ & - & & 72 & $\mathrm{~b}$ & 65 & $\mathrm{~b}$ \\
\hline & 2 & 1 st ratoon & 127 & $\mathrm{a}$ & 120 & $\mathrm{ab}$ & 116 & $\mathrm{~b}$ & 107 & $\mathrm{c}$ \\
\hline & & 2 nd ratoon & 120 & $\mathrm{a}$ & 117 & $\mathrm{a}$ & 117 & $\mathrm{a}$ & 108 & $\mathrm{~b}$ \\
\hline & & 3 rd ratoon & 92 & $\mathrm{a}$ & 87 & $\mathrm{a}$ & 76 & $\mathrm{~b}$ & 76 & $\mathrm{~b}$ \\
\hline & 3 & 1 st ratoon & 155 & $\mathrm{a}$ & - & $£$ & 154 & $\mathrm{a}$ & 139 & $\mathrm{~b}$ \\
\hline & & 2 nd ratoon & 154 & $\mathrm{a}$ & - & & 140 & $\mathrm{~b}$ & 142 & $\mathrm{~b}$ \\
\hline & & 3 rd ratoon & 143 & $\mathrm{a}$ & - & & 146 & $\mathrm{a}$ & 144 & $\mathrm{a}$ \\
\hline & & 4th ratoon & 158 & $\mathrm{a}$ & - & & 153 & $a b$ & 144 & $\mathrm{a}$ \\
\hline & 4 & 1 st ratoon & 108 & $\mathrm{a}$ & 106 & $\mathrm{a}$ & 102 & $\mathrm{a}$ & 92 & $\mathrm{~b}$ \\
\hline & 5 & 1 st ratoon & 154 & $\mathrm{~b}$ & 147 & $\mathrm{~b}$ & 148 & $\mathrm{~b}$ & 165 & $\mathrm{a}$ \\
\hline & & 2nd ratoon & 132 & $\mathrm{a}$ & 131 & $\mathrm{a}$ & 128 & a & 129 & $\mathrm{a}$ \\
\hline & 6 & 1 st ratoon & 130 & $\mathrm{~b}$ & 127 & $\mathrm{~b}$ & 124 & $\mathrm{~b}$ & 143 & $\mathrm{a}$ \\
\hline & & 2nd ratoon & 155 & $\mathrm{a}$ & 166 & $\mathrm{a}$ & 160 & $\mathrm{a}$ & 154 & $\mathrm{a}$ \\
\hline \multirow[t]{16}{*}{ Western São Paulo } & 7 & 1 st ratoon & 120 & $\mathrm{a}$ & 102 & $\mathrm{~b}$ & 100 & $\mathrm{~b}$ & 98 & $\mathrm{~b}$ \\
\hline & & 2 nd ratoon & 65 & $\mathrm{ab}$ & 73 & $\mathrm{a}$ & 58 & $\mathrm{bc}$ & 54 & $\mathrm{c}$ \\
\hline & & 3 rd ratoon & 62 & $\mathrm{a}$ & 54 & $\mathrm{~b}$ & 56 & $\mathrm{~b}$ & 51 & $\mathrm{a}$ \\
\hline & & 4 th ratoon & 41 & $\mathrm{a}$ & 38 & $\mathrm{a}$ & 37 & $\mathrm{a}$ & 30 & $\mathrm{~b}$ \\
\hline & 8 & 1 st ratoon & 120 & $\mathrm{a}$ & 120 & $\mathrm{~b}$ & 93 & $\mathrm{~b}$ & 96 & $\mathrm{~b}$ \\
\hline & & 2 nd ratoon & 106 & $\mathrm{a}$ & 111 & $\mathrm{a}$ & 105 & $\mathrm{a}$ & 109 & $\mathrm{a}$ \\
\hline & & 3rd ratoon & 85 & $a b$ & 88 & $\mathrm{a}$ & 78 & $a b$ & 70 & $\mathrm{~b}$ \\
\hline & & 4th ratoon & 75 & $\mathrm{a}$ & 73 & $a b$ & 64 & $a b$ & 63 & $\mathrm{~b}$ \\
\hline & 9 & 1 st ratoon & 87 & $\mathrm{a}$ & - & $£$ & 85 & $\mathrm{a}$ & 91 & $\mathrm{a}$ \\
\hline & & 2 nd ratoon & 76 & $\mathrm{a}$ & - & & 76 & $\mathrm{a}$ & 69 & $\mathrm{a}$ \\
\hline & & 3rd ratoon & 37 & $\mathrm{a}$ & - & & 38 & $\mathrm{a}$ & 33 & $\mathrm{a}$ \\
\hline & & 4th ratoon & 30 & $\mathrm{a}$ & - & & 33 & $\mathrm{a}$ & 35 & $\mathrm{a}$ \\
\hline & $10^{\S}$ & 1st ratoon & 59 & $\mathrm{a}$ & 70 & $\mathrm{a}$ & 57 & $\mathrm{a}$ & 60 & $\mathrm{a}$ \\
\hline & & 2 nd ratoon & 33 & $\mathrm{~b}$ & 38 & $\mathrm{ab}$ & 41 & $\mathrm{a}$ & 36 & $\mathrm{ab}$ \\
\hline & $11^{\S}$ & 1st ratoon & 73 & $\mathrm{a}$ & 78 & $\mathrm{a}$ & 69 & $a b$ & 57 & $\mathrm{~b}$ \\
\hline & & 2 nd ratoon & 21 & $\mathrm{a}$ & 21 & $\mathrm{a}$ & 22 & $\mathrm{a}$ & 20 & $\mathrm{a}$ \\
\hline \multirow[t]{13}{*}{ Central-eastern São Paulo } & 12 & 1 st ratoon & 84 & $\mathrm{a}$ & 80 & $\mathrm{a}$ & 80 & a & 82 & $\mathrm{a}$ \\
\hline & & 2nd ratoon & 90 & $\mathrm{a}$ & 87 & $\mathrm{a}$ & 94 & a & 95 & $\mathrm{a}$ \\
\hline & & 3rd ratoon & 86 & $\mathrm{a}$ & 85 & $\mathrm{a}$ & 83 & $\mathrm{a}$ & 96 & $\mathrm{a}$ \\
\hline & & 4th ratoon & 92 & $\mathrm{a}$ & 96 & $\mathrm{a}$ & 88 & a & 94 & $\mathrm{a}$ \\
\hline & & 5 th ratoon & 67 & $\mathrm{a}$ & 67 & $\mathrm{a}$ & 57 & $\mathrm{a}$ & 67 & $\mathrm{a}$ \\
\hline & 13 & 1 st ratoon & 118 & $\mathrm{a}$ & 116 & $\mathrm{a}$ & 117 & $\mathrm{a}$ & 110 & $\mathrm{a}$ \\
\hline & & 2 nd ratoon & 123 & $\mathrm{a}$ & 122 & $\mathrm{a}$ & 127 & $\mathrm{a}$ & 123 & $\mathrm{a}$ \\
\hline & & 3 rd ratoon & 62 & $\mathrm{a}$ & 54 & $\mathrm{a}$ & 59 & $\mathrm{a}$ & 55 & $\mathrm{a}$ \\
\hline & & 4 th ratoon & 65 & $\mathrm{a}$ & 63 & $\mathrm{a}$ & 70 & $\mathrm{a}$ & 64 & $\mathrm{a}$ \\
\hline & & 5 th ratoon & 73 & $\mathrm{a}$ & 63 & $\mathrm{a}$ & 58 & $\mathrm{a}$ & 65 & $\mathrm{a}$ \\
\hline & 14 & 1 st ratoon & 93 & $\mathrm{a}$ & - & $£$ & 92 & $\mathrm{a}$ & 99 & $\mathrm{a}$ \\
\hline & & 2 nd ratoon & 71 & $\mathrm{~b}$ & - & & 72 & $\mathrm{~b}$ & 92 & $\mathrm{a}$ \\
\hline & & 3rd ratoon & 26 & $\mathrm{~b}$ & - & & 33 & $a b$ & 42 & $\mathrm{a}$ \\
\hline
\end{tabular}


Table 3 (continued)

\begin{tabular}{|c|c|c|c|c|c|c|c|c|c|c|}
\hline \multirow[t]{2}{*}{ Region } & \multirow[t]{2}{*}{ Site } & \multirow[t]{2}{*}{ Evaluation period } & \multicolumn{8}{|c|}{ Straw removal } \\
\hline & & & NR & & LR & & MR & & TR & \\
\hline & \multirow[t]{3}{*}{15} & 1st ratoon & 81 & $\mathrm{~b}$ & 87 & $a b$ & 88 & $\mathrm{ab}$ & 91 & $\mathrm{a}$ \\
\hline & & 2 nd ratoon & 44 & $\mathrm{a}$ & 48 & $\mathrm{a}$ & 48 & $\mathrm{a}$ & 49 & $\mathrm{a}$ \\
\hline & & 3rd ratoon & 38 & $\mathrm{a}$ & 39 & $\mathrm{a}$ & 38 & $\mathrm{a}$ & 38 & $\mathrm{a}$ \\
\hline & \multirow[t]{2}{*}{16} & 1 st ratoon & 123 & $\mathrm{a}$ & 124 & $\mathrm{a}$ & 127 & $\mathrm{a}$ & 128 & $\mathrm{a}$ \\
\hline & & 2 nd ratoon & 83 & $\mathrm{~b}$ & 84 & $\mathrm{~b}$ & 86 & $\mathrm{~b}$ & 99 & $\mathrm{a}$ \\
\hline & \multirow[t]{2}{*}{$17^{\S}$} & 1 st ratoon & 97 & $\mathrm{a}$ & 98 & a & 100 & a & 95 & $\mathrm{a}$ \\
\hline & & 2 nd ratoon & 61 & $\mathrm{a}$ & 70 & a & 68 & $\mathrm{a}$ & 60 & a \\
\hline & \multirow[t]{2}{*}{$18^{\S}$} & 1st ratoon & 122 & $\mathrm{ab}$ & 126 & a & 123 & $\mathrm{a}$ & 105 & $\mathrm{~b}$ \\
\hline & & 2 nd ratoon & 69 & $\mathrm{a}$ & 68 & $\mathrm{a}$ & 70 & $\mathrm{a}$ & 74 & $\mathrm{a}$ \\
\hline & 19 & 1 st ratoon & 116 & $\mathrm{a}$ & 119 & $\mathrm{a}$ & 118 & $\mathrm{a}$ & 117 & $\mathrm{a}$ \\
\hline & $20^{\S}$ & 1st ratoon & 63 & $\mathrm{a}$ & 64 & a & 69 & $\mathrm{a}$ & 64 & $\mathrm{a}$ \\
\hline & $21^{\S ¥}$ & 1st ratoon & 68 & & 71 & & 76 & & 74 & \\
\hline & $22^{\S ¥}$ & 2 nd ratoon & 72 & & 77 & & 83 & & 84 & \\
\hline & 23 & 4th ratoon & 87 & $\mathrm{a}$ & 84 & $\mathrm{a}$ & 88 & $\mathrm{a}$ & 62 & $\mathrm{~b}$ \\
\hline & 24 & 3rd ratoon & 61 & $\mathrm{a}$ & 53 & $a b$ & 50 & $a b$ & 42 & $\mathrm{~b}$ \\
\hline \multirow[t]{7}{*}{ Northeastern São Paulo } & \multirow[t]{2}{*}{25} & 2 nd ratoon & 87 & $a b$ & 93 & $\mathrm{a}$ & 91 & $\mathrm{a}$ & 79 & $\mathrm{~b}$ \\
\hline & & 3rd ratoon & 100 & $\mathrm{a}$ & 100 & a & 101 & $\mathrm{a}$ & 91 & $\mathrm{~b}$ \\
\hline & \multirow[t]{2}{*}{26} & 1st ratoon & 119 & $\mathrm{a}$ & 111 & $\mathrm{~b}$ & 124 & $\mathrm{a}$ & 119 & $\mathrm{a}$ \\
\hline & & 2 nd ratoon & 105 & $\mathrm{a}$ & 97 & $\mathrm{a}$ & 98 & $\mathrm{a}$ & 96 & $\mathrm{a}$ \\
\hline & \multirow[t]{2}{*}{27} & 8 th ratoon & 87 & $\mathrm{a}$ & 85 & $\mathrm{a}$ & - & $£$ & 86 & $\mathrm{a}$ \\
\hline & & 9th ratoon & 85 & $\mathrm{a}$ & 90 & $\mathrm{a}$ & - & & 89 & $\mathrm{a}$ \\
\hline & 28 & 1st ratoon & 107 & $\mathrm{~b}$ & 109 & $\mathrm{~b}$ & 107 & & 128 & $\mathrm{a}$ \\
\hline
\end{tabular}

$N R, L R, M R$, and $T R$ denote no, low, moderate, and total straw removal rates, respectively. Means in the row followed by the same letter do not differ from each other according to Tukey's test $(p<0.05) .{ }^{£}$ Treatment was not evaluated. ${ }^{\S}$ Data from literature. ${ }^{\ddagger}$ Data to run statistical test were not available in the publication

removal were observed in sites 7 and 8 , where sugarcane was harvested in the early (April) and late (October) harvesting seasons, respectively. Conversely, on site 9, where sugarcane was harvested in the middle season (June/July), the removal of straw did not significantly change sugarcane yields (Fig. 3).

Overall, absolute and relative yield responses due to straw removal in central-eastern and northeastern São Paulo were quite low and tended to be zero (Fig. 2). However, substantial variation in yield responses were observed among sites within both regions (Figs. 5 and 6). In central-eastern São Paulo, the straw removal significantly increased sugarcane yields in sites $14,15,16$, and 18, decreased in sites 23 and 24, and have no significant effects in sites 12,13,17, 19, 20, 21, and 22 (Table 3). Comparing with NR treatment, only TR induced site-specific changes in sugarcane yield in this region (Fig. 5). There were no clear regional patterns of straw removal effects on sugarcane yields in northeastern São Paulo (Fig. 6). In site 25, a significant reduction in sugarcane yields was observed for TR, while an opposite response was observed in site 28 . In other sites, the straw removal did not significantly change sugarcane yield (Table 3 ).

\section{Sugarcane Yield Change Index: Stalk Gain/Loss per Unit of Straw Removed}

The intensity of straw removal effects on stalk yield, indicated as SYC index, changed according to locations, soil types, harvesting seasons, and crop aging conditions (Table 4). On a regional scale, the effect of each megagram of straw removed from the field on crop yield was more relevant for southern Goiás. Considering only the values in which the linear regressions were significant $(p<0.05)$, average SYC index values for sites $1,2,3$, 4,5 , and 6 were $-1.81,-1.05,-0.88,0.91,0.74$, and -1.02 , respectively (Table 4 ). The positive SYC indexes on sites 4 and 5 , suggesting that under specific soil and management conditions that prevent water deficit straw removal, may increase sugarcane yields. In western São Paulo, significant linear regressions indicated that straw removal reduces sugarcane yields (i.e., SYC indexes ranging from -0.20 to -1.66 ). However, there was a large variation in SYC index between crop years and mainly among different sites at the same region. Thus, although the regional SYC index can provide a comprehensive overview of the crop responsiveness to straw removal management, 
Fig. 3 Loss (negative bars) and gain (positive bars) of sugarcane yield $\left(\mathrm{Mg} \mathrm{ha}{ }^{-1}\right.$ year $\left.^{-1}\right)$ in response to straw removal in southern Goiás. Yield gain or loss induced by LR, low removal; MR, moderate removal; and TR, total removal in relation to NR, no removal (baseline treatment). Different bars within each site represent the ratoon cycles. na indicates that the treatment was not evaluated in that site. Asterisk (*) symbol indicates significant difference between the treatment of straw removal and baseline (no removal)

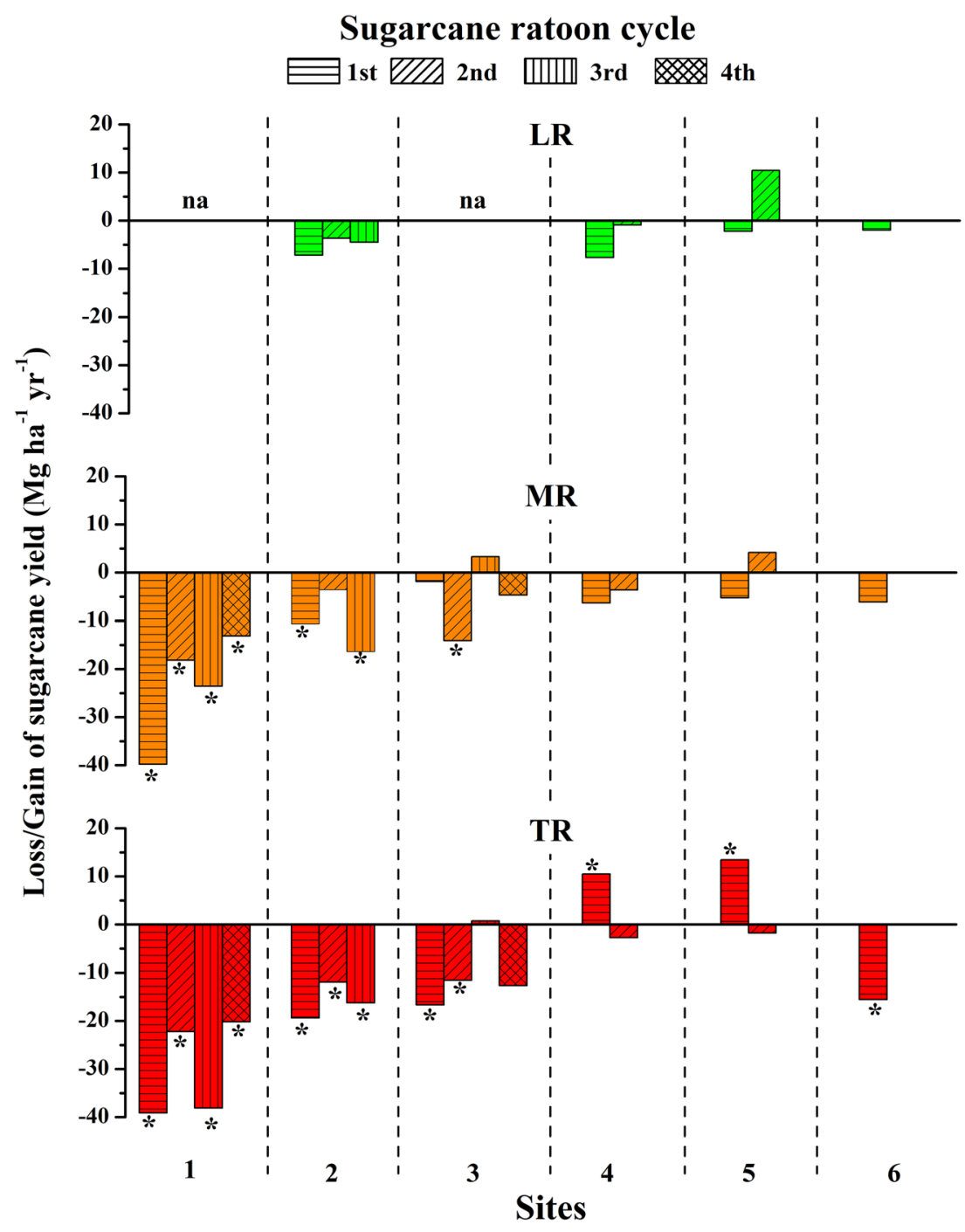

specific index for each site should be preferably adopted, since it better represents local soil and management conditions.

In central-eastern São Paulo, as shown from previous results, SYC index did not show a clear regional pattern. Based only on significant results, SYC indexes ranged from -0.18 to 1.01, indicating that site-specific conditions modulated crop response to straw removal. A similar pattern was observed in northeastern São Paulo (Table 4).

\section{Discussion}

\section{Overall Implications of Straw Removal on Soil-Plant Systems}

Sugarcane straw, a crop residue composed by top and dry leaves, has a dual purpose and can be maintained in the fields or be used to produce bioenergy [24]. The maintenance of straw on the soil surface results in several well-known ecosystem services, such as nutrient recycling [25], carbon storage [6], erosion control [26], soil water retention [27], increases in soil biodiversity [28], reduction of soil compaction [22], and weed control [8]. However, the maintenance of large amount of straw in the field may result in some drawbacks such as higher $\mathrm{N}_{2} \mathrm{O}$ emissions [29], higher pest infestation [30], and slower crop regrowth [5], especially in cooler regions [31]. Therefore, complex interactions between straw and soil properties coupled with different management practices adopted by the farmers make crop responses to straw removal harder to be predicted by isolate/local studies. Based on this multilocation study, we seek to answer some questions that are fundamentally essential for guiding more sustainable straw management in Brazil. What is the direct impact of straw removal on sugarcane yields? What are the main drivers influencing sugarcane yield changes in south-central Brazil? How can we recommend straw removal rates without compromising sugarcane yields? In the following subsections, we discussed our data to provide scientific basis to answer these questions. 
Fig. 4 Loss (negative bars) and gain (positive bars) of sugarcane yield $\left(\mathrm{Mg} \mathrm{ha}{ }^{-1}\right.$ year $\left.^{-1}\right)$ in response to straw removal in the western region of São Paulo state. Yield gain or loss induced by LR, low removal; MR, moderate removal; and TR, total removal in relation to NR, no removal (baseline treatment). Different bars within each site represent the ratoon cycles. na indicates that the treatment was not evaluated in that site. Asterisk (*) symbol indicates significant difference between the treatment of straw removal and baseline (no removal)

\section{Sugarcane ratoon cycle}

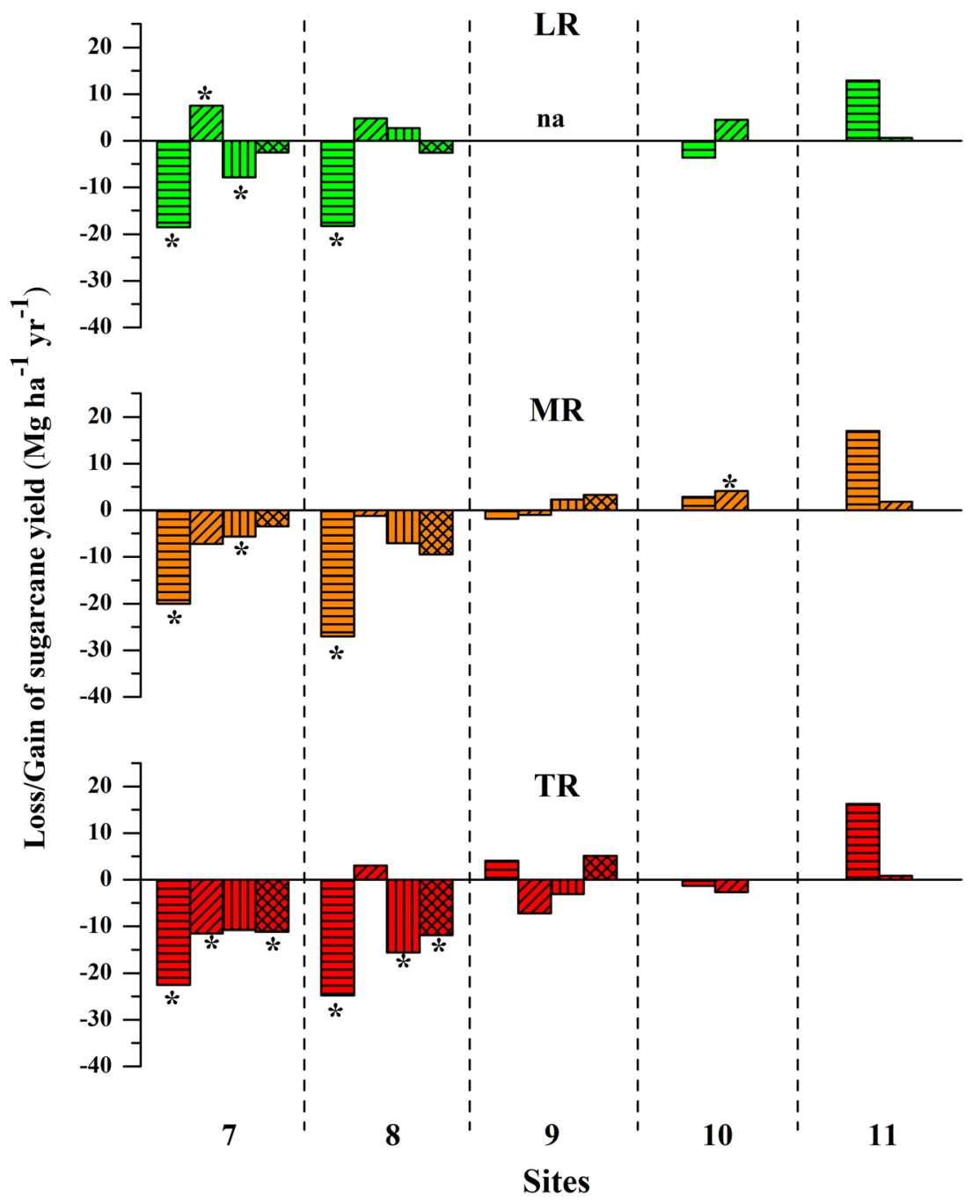

\section{Regional Effects of Straw Removal on Sugarcane Yield}

The south-central region is the largest core of sugarcane production in Brazil, representing 92\% of national production of sugarcane [9]. In that region, sugarcane cultivation extends for 9.1 million ha [9], including a wide range of climatic conditions [32]. Several studies have indicated a direct relationship between crop yield and/or yield response to straw management with regional variations on climatic conditions in south-central Brazil [4, 5, 12, 33-35]. In our study, the sugarcane yield varied on a regional scale, indicating average yields of $129,64,82$, and $99 \mathrm{Mg} \mathrm{ha}^{-1}$ of fresh stalk in southern Goiás and western, central-eastern, and northern São Paulo, respectively (Table 3). The higher sugarcane yields in southern Goiás relative to those in São Paulo regions can be associated with several factors including the high mean and minimal temperature and higher solar radiation that increases photosynthetic rates and sugarcane growth [33]. Our results agree with those of Dias and Sentelhas [4], who pointed out that traditional areas under sugarcane plantation in São Paulo present lower yield potential compared with the south region of Goiás. Additionally, it is worth mentioning that Goiás experienced an intensive expansion (120\%) of sugarcane area in the past decade, increasing from 0.495 (2007/08) to 1.107 million ha (2017/18) [2]. Therefore, most of sugarcane areas in Goiás still present lower occurrence of pests and diseases, and the soils are less compacted, all of which are key factors that substantially impair crop yields in the most intensively cultivated sugarcane region in the São Paulo state. Several studies worldwide have indicated that the long-term sugarcane monoculture under mechanized conditions, such as those observed in São Paulo state, leads to soil degradation, which is considered the main cause of the sugarcane yield declines in traditional production areas [36-38].

The location of the sites within the four macroregions was one effective individual factor to explain the effects of straw removal on sugarcane yields. The higher yield response to straw removal was observed in southern Goiás and western 


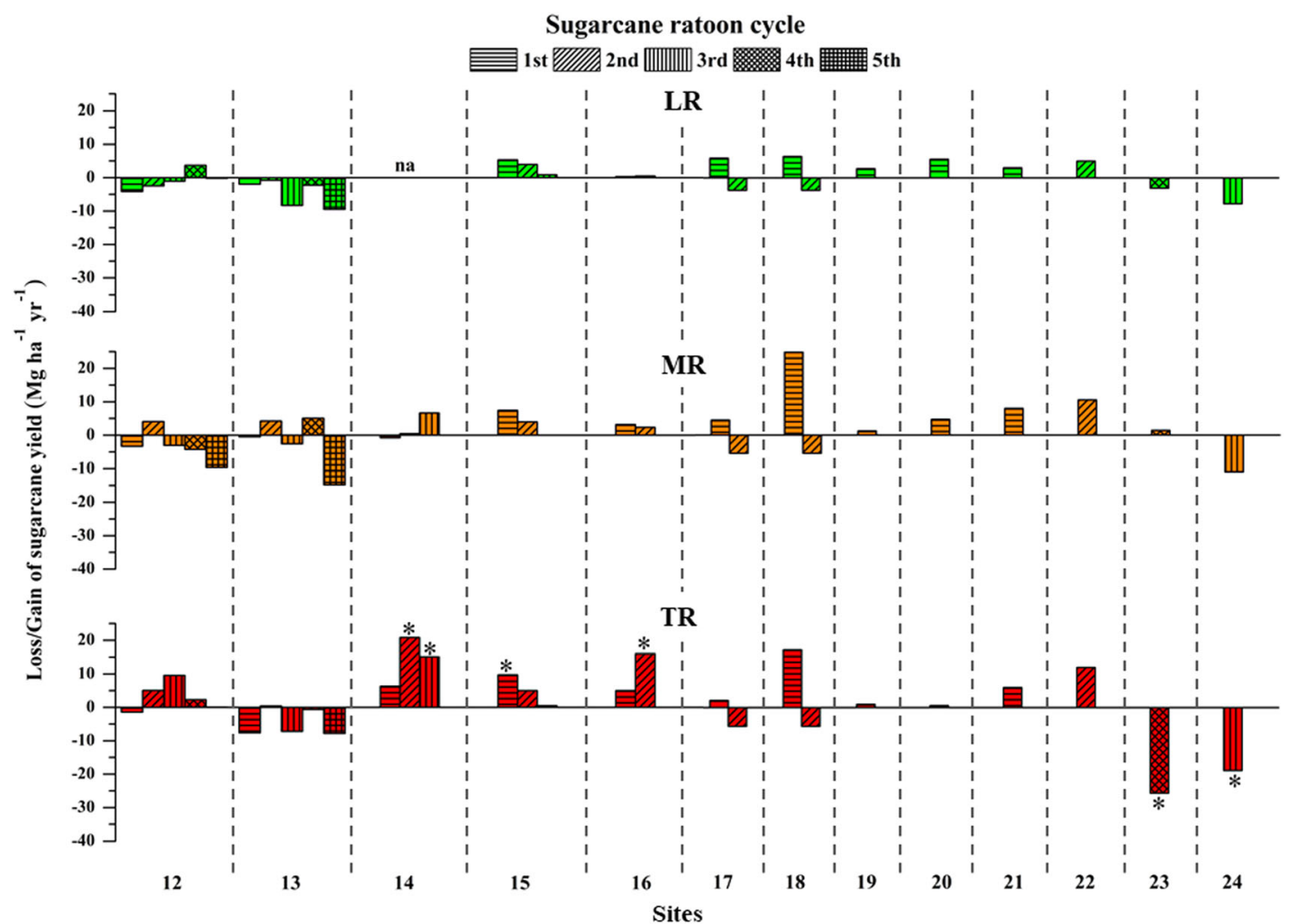

Fig. 5 Loss (negative bars) and gain (positive bars) of sugarcane yield $\left(\mathrm{Mg} \mathrm{ha}^{-1}\right.$ year $\left.^{-1}\right)$ in response to straw removal in central-east region of São Paulo state. Yield gain or loss induced by LR, low removal; MR, moderate removal; and TR, total removal in relation to NR, no removal

São Paulo (Fig. 2 and Table 4). Conversely, the average crop responsiveness to straw removal was practically insignificant in central-eastern São Paulo (Fig. 5), which is slight cooler than other regions. It is important to highlight that, although the average daily minimal temperature ranges from 15.8 to $17.2^{\circ} \mathrm{C}$ (Table 1), in this region, there are periods of the day in which the temperature is below $10^{\circ} \mathrm{C}$. The soil temperature for a proper sugarcane development ranges from 20 to $30^{\circ} \mathrm{C}$ [39]; thus, crop growth is inhibited when plants are submitted to temperatures below $15^{\circ} \mathrm{C}$, while below $10^{\circ} \mathrm{C}$, some injuries may occur [40]. In this case, especially in cooler regions such as central-eastern São Paulo, a moderate removal of straw from the soil surface may improve regrowth of sugarcane [5] and stalk yields (Fig. 2).

Climate effects on yield response to straw removal are associated with limiting and responsive factors. Low temperature is a limiting factor that can restrict sugarcane initial tillering and growth and eventually impair crop yield, while solar radiation and precipitation are responsive factors [41]. The most accentuated reduction of crop yield induced by straw removal in southern Goiás can be associated with the best conditions of temperature and solar radiation (i.e., higher crop yield potential), and also because this region presents a higher water deficit in winter season. Straw mulching is also fundamental to reducing water losses and increasing soil moisture (baseline treatment). Different bars within each site represent the ratoon cycles. na indicates that the treatment was not evaluated in the site. Asterisk (*) symbol indicates significant difference between the treatment of straw removal and baseline (no removal)

[27]. Thus, the combination of these aspects makes this region more responsive to straw management, suggesting that recommendations for straw removal should be carefully analyzed. These findings are aligned with previous results showing that straw removal can be more detrimental to sugarcane yield in the central region of Brazil [12, 33].

\section{Soil Texture Affecting Sugarcane Yield Response to Straw Removal}

Soil texture is a key factor that regulates water and nutrient balance into soil profile, which are crucial characteristics defining the sugarcane yield capacity. Our results corroborate this statement with average sugarcane yields of 99,80 , and $66 \mathrm{Mg} \mathrm{ha}^{-1}$ for clayey, loamy, and sandy soils, respectively. Sandy soils have a predominance of macropores, promoting faster water drainage and reduced capacity of water retention relative to clay soils [42]. Therefore, clay soils sustained greater sugarcane yields than sandy soils, as consistently reported in the literature [5, 12,35].

Since sandy soils show more adverse conditions to sustaining higher crop production, we hypothesized that straw removal effects on sugarcane yield would be more detrimental in this soil type than in fine-textured soils. Nevertheless, contrary to our expectation, soils under distinct textures were 
Fig. 6 Loss and gain of sugarcane yield $\left(\mathrm{Mg} \mathrm{ha}^{-1}\right.$ year $\left.^{-1}\right)$ in northeastern region of São Paulo state. Yield gain or loss induced by LR, low removal; MR, moderate removal; and TR, total removal in relation to NR, no removal (baseline treatment). Different bars within each site represent the ratoon cycles. na indicates that the treatment was not evaluated in that site. Asterisk (*) symbol indicates significant difference between the treatment of straw removal and baseline (no removal) response to straw removal in

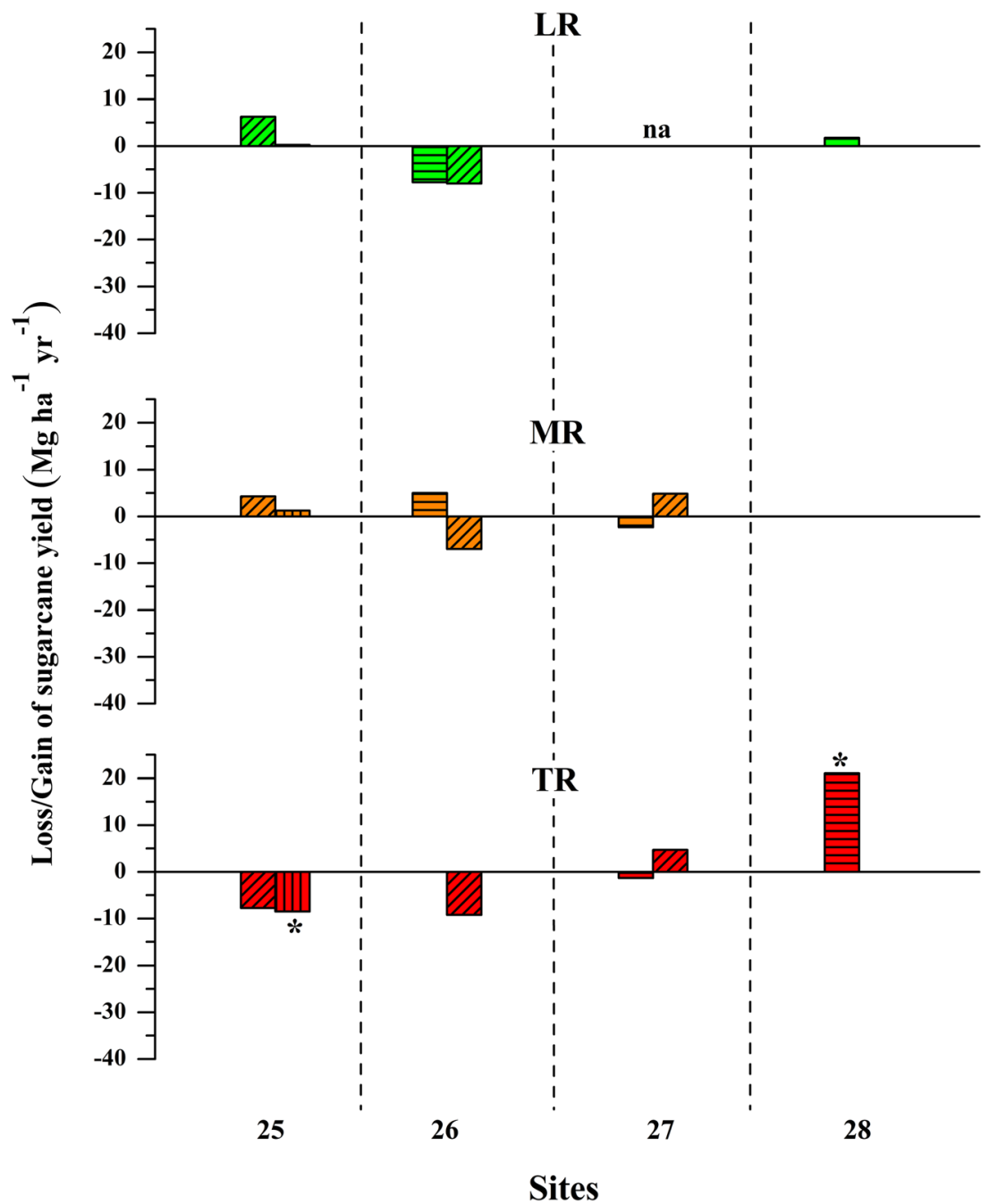

responsive to straw removal, and the highest SYC indexes were observed in clayey soils in Goiás state. The higher sugarcane yield responses to straw removal in fine-textured soils (clayey) are associated with higher water storage capacity, which results in a high capacity to respond to management practices, especially when the water is the main limiting factor for sugarcane growth. The maintenance of straw also increases soil carbon stocks $[12,43]$ and consequently tends to improve water-use efficiency in sugarcane fields [44]. Additionally, the benefits of straw mulching go beyond of soil water, since it contributes for soil organic matter formation, which plays an important role in improving cation exchange capacity in highly weathered tropical soils [45].

Although soil texture is an important controlling factor of sugarcane yield response, similar soils presented distinct patterns in different climate regions, suggesting that this factor in isolation does not explain the yield changes. In southern Goiás, most of SYC index values from clayey soils revealed yield losses due to straw removal, whereas yield gains were observed only in two sites (site 4-clayey soil under hydromorphic character and site 5-clayey soil under full irrigation), where water deficit was not a limiting factor to plant growth. In these conditions of adequate or excessive water supply, the removal of sugarcane straw tends to increase stalk yields. It reinforces that, at least in the short term, the main benefit of straw maintenance on soil surface is related to preserve soil moisture and reduce water stress to plants. Conversely, the sugarcane response to straw removal in less responsive regions shows no consistent results (Figs. 4 and 5), suggesting that crop yield response was likely dependent on other factors, such as local weather conditions, harvesting season, and pest and weed infestation.

\section{Seasonal Effects of Straw Removal on Sugarcane Yield}

Sugarcane harvesting seasons in south-central Brazil extend from March to November. The decision-making on the sugarcane harvest period is associated with the planting date and crop variety. Currently, there are more than one hundred commercial sugarcane varieties from different companies/research 
Table 4 Sugarcane Yield Change index (SYC index - $\mathrm{Mg}$ stalk $\mathrm{Mg}^{-1}$ of straw removed from the field) grouped by macroregions and sites. Index was obtained by linear regression using the exact amount of straw removed from the field in each site/year and the response of crop in terms of stalk yield. Negative and positive values indicate yield gains and losses induced by straw removal, respectively

\begin{tabular}{|c|c|c|c|c|c|c|c|c|}
\hline \multirow[t]{2}{*}{ Regions } & \multirow[t]{2}{*}{ Sites } & \multicolumn{7}{|c|}{ Period of evaluation (ratoons) } \\
\hline & & 1 st & 2nd & $3 \mathrm{rd}$ & 4th & 5 th & 8th & 9th \\
\hline \multirow[t]{6}{*}{ Southern Goiás } & 1 & $-2.37 *$ & $-1.34 *$ & $-2.31 *$ & $-1.22 *$ & - & - & - \\
\hline & 2 & $-1.23 *$ & $-0.71 *$ & $-1.21 *$ & - & - & - & - \\
\hline & 3 & $-1.12 *$ & $-0.73 *$ & -0.05 & $-0.80^{*}$ & - & - & - \\
\hline & 4 & $0.91 *$ & -0.22 & - & - & - & - & - \\
\hline & 5 & $0.74 *$ & -0.23 & - & - & - & - & - \\
\hline & 6 & $-1.02 *$ & - & - & - & - & - & - \\
\hline \multirow[t]{5}{*}{ Western São Paulo } & 7 & $-1.38^{*}$ & $-0.99 *$ & $-0.67 *$ & $-0.69 *$ & - & - & - \\
\hline & 8 & $-1.66^{*}$ & 0.06 & $-1.13 *$ & $-0.85^{*}$ & - & - & - \\
\hline & 9 & 0.40 & $-1.09 *$ & -0.31 & 0.51 & - & - & - \\
\hline & 10 & -0.04 & 0.03 & - & - & - & - & - \\
\hline & 11 & $-0.20 *$ & -0.01 & - & - & - & - & - \\
\hline \multirow[t]{13}{*}{ Central-eastern São Paulo } & 12 & -0.07 & 0.61 & 0.53 & -0.02 & -0.50 & - & - \\
\hline & 13 & -0.48 & 0.12 & -0.31 & 0.11 & -0.58 & - & - \\
\hline & 14 & 0.42 & $0.98 *$ & $1.01 *$ & - & - & - & - \\
\hline & 15 & $0.63 *$ & 0.30 & 0.01 & - & - & - & - \\
\hline & 16 & 0.36 & $1.00 *$ & - & - & - & - & - \\
\hline & 17 & -0.01 & -0.03 & - & - & - & - & - \\
\hline & 18 & $-0.18 *$ & 0.05 & - & - & - & - & - \\
\hline & 19 & 0.03 & - & - & - & - & - & - \\
\hline & 20 & 0.26 & - & - & - & - & - & - \\
\hline & 21 & 0.31 & - & - & - & - & - & - \\
\hline & 22 & $0.84 *$ & - & - & - & - & - & - \\
\hline & 23 & - & - & - & $-1.45^{*}$ & - & - & - \\
\hline & 24 & - & - & $-1.20 *$ & - & - & - & - \\
\hline \multirow[t]{4}{*}{ Northeastern São Paulo } & 25 & - & $-0.80 *$ & -0.49 & - & - & - & - \\
\hline & 26 & 0.26 & -0.61 & - & - & - & - & - \\
\hline & 27 & - & - & - & - & - & -0.11 & 0.36 \\
\hline & 28 & 1.23 & - & - & - & - & - & - \\
\hline
\end{tabular}

*The linear regression to obtain SYC index was significant $(p<0.05)$

institutions and those are grouped within three maturation seasons, early (March-May), middle (June-August), and late (September-November). During each harvesting season, the weather conditions and management practices (including straw removal) can favor or delay sugarcane tillering, development, and growth. Therefore, crop yield responses to straw removal also depend on harvesting seasons [5].

In our study, when sites under similar soil and weather conditions were compared (sites 7,8, and 9), there was a prominent effect of harvesting season in determining the response of straw removal on crop yield. For example, the sugarcane harvesting in site 7 occurred in early season (April), at the end of the rainy period, when the soil presents suitable moisture and temperature for a rapid sprouting, tillering, and initial growth of sugarcane. The dry season starts after this initial stage of crop development, and the straw layer has direct effects on preserving soil moisture to support the plant growth during the dry period. In general, the removal of straw in this site significantly reduced crop yields (Fig. 4). Conversely, when sugarcane is harvested in the middle season (i.e., winter), the soil presents lower moisture and temperature, which results in slow tillering and initial growth [5], especially in cooler regions of São Paulo. For this period, Gmach et al. [27] estimated that the complete maintenance of straw (12 $\mathrm{Mg} \mathrm{ha}^{-1}$ ) or even partial maintenance $\left(6 \mathrm{Mg} \mathrm{ha}^{-1}\right.$ ) delays water-limiting condition to plants for approximately 1 month in relation to soil without straw (TR). Finally, when the harvesting and straw deposition occur in late season (beginning of the rainy and warmer seasons), sugarcane tillering occurs very fast and straw 
layer helps to preserve soil moisture for plant growth until the canopy closure [44], and after this period, the microclimate created by sugarcane crop can control soil water dynamics.

The seasonal effects of straw removal on sugarcane yields can also be observed between the areas located in Iracemápolis (sites 12,13, and 14), which is a climatic region with low responsiveness to straw removal (Fig. 2). For this location, straw removal did not significantly change the yields in the early and late harvesting periods and induced a significant yield gain in the area harvested in the middle season (site 14). The maintenance of thick layers of straw in cooler seasons can hinder the sugarcane tillering and regrowth $[5,31]$, that, in some cases, may reduce sugarcane yield [46]. However, it is important to highlight that the influence of the harvesting seasons on straw removal recommendations is relevant only in the regions with remarkable changes in weather conditions along the year. For example, in south Goiás, a region characterized by warmer temperatures along the year (Table 1), the sugarcane crop was responsive to straw removal independently of the harvesting season.

\section{Crop Aging Effects of Straw Removal on Sugarcane Yield}

The sugarcane crop cycle typically extends for 5-6 years, which includes the plant-cane cycle and the ratoons that are subsequently grown/harvested annually until the sugarcane yield becomes economically and technically unfeasible and a new planting is required [47]. The impact of crop aging on sugarcane yield is well-known and in general, a significant yield reduction along the cycle is associated with several factors such as (i) crop damages caused by field operations [5]; (ii) increased soil compaction caused by machine traffic [48]; (iii) lower soil nutrient availability due to annual extraction by sugarcane stalks [49]; and (iv) higher proliferation of pests and diseases [50].

However, the effect of crop aging on sugarcane yield response to straw removal is not well understood. When some sites were analyzed separately, particularly those where several ratoons were evaluated, our results showed that the effects of straw removal on sugarcane yields tend to be higher in younger ratoons (Figs. 3, 4, 5, and 6), indicating that the crop is more responsive to management practices. This higher response of sugarcane crop in younger ratoons is associated with several factors, including high crop yield potential, high plant stand [51, 52], high soil fertility [25], low pest and weed infestation [50], and low soil compaction [48] at the beginning of the sugarcane cycle. Such pattern can be clearly observed in sites 1,2,3,7, and 8 (Figs. 3 and 4), where the evaluation was more representative of the entire crop cycle and crop yield was responsive to straw removal.

\section{Summary and Final Remarks}

Straw represents one-third of the energy potential of the sugarcane crop [53] and until 15 years ago, this crop residue was burned prior to harvesting. With the widespread adoption of green cane harvesting in Brazil, the straw has been maintained in the field as soil amendment [47]. While straw can benefit the long-term soil quality and crop yield, such residues also represent a valuable feedstock for bioenergy production and enable new opportunities for the Brazilian sugarcane industry [8]. However, there exists a current lack of a guideline for recommendable amount of straw that can be sustainably removed without impairing the soil-plant system.

Our findings indicated that the impacts of straw removal on sugarcane yields are guided by a complex equation and dependent on numerous factors including local weather conditions, soil types, harvesting seasons, and crop aging. There is no single answer to recommend straw removal in southcentral Brazil, so that the recommendation in a sustainably compatible manner should be prioritized as follows: (i) the first step is to identify the regional weather condition, since it was the most prominent factor that influenced the responses of sugarcane yield to straw removal management. Based on the minimal temperature, water deficit, and solar radiation of each specific region, we can predict how sugarcane crop is responsive to straw removal; (ii) soil type was an important factor but it should be analyzed within a specific region and generalizations about the straw removal according to soil type should be avoided. The magnitude of the changes was highly variable between soil types, where straw removal led to highest yield losses in soils with higher yield potential (i.e., clayey soils with high fertility) such as southern Goiás. Special attention should be taken for soils that exhibit water surplus under natural conditions (such as hydromorphic soils and shallow soils with water table near the surface) or fullirrigated system. In these environments, straw removal may increase sugarcane yields; (iii) harvesting season is another important factor, especially in regions where the minimal temperature is restrictive to sugarcane growth. Effects of minimal temperature on crop tillering, growth, and development are observed only when sugarcane is harvested in the early and middle seasons. This evidence is irrelevant when sugarcane is harvested after September (late season), since the minimal temperatures are suitable for crop growth in the most intensively cultivated sugarcane regions in south-central Brazil; (iv) lastly, the inclusion of crop aging in this complex equation can improve the recommendation of straw removal without significant yield losses. Our findings indicated that younger ratoons are more responsive to straw removal, resulting in higher yield losses compared with older ratoons.

Conclusions drawn from this study suggest that straw removal is a feasible reality for years to come, enabling new opportunities for the Brazilian sugarcane industry. However, 
straw management recommendations cannot be designed based on isolated factor but require holistic and integrated knowledge to ensure that straw amount left on field is enough to sustain multiple soil ecosystem services (e.g., protection against soil erosion, soil organic matter accretion, nutrient cycling, biodiversity maintenance) and crop yields. As far as the benefits of straw to the soil-plant system are integrally concerned, higher rates of straw removal can be performed in regions less responsive such as central-eastern and northeastern São Paulo, while only lower removal rates can be feasible in regions prone to yield losses (e.g., southern Goiás and western São Paulo) on a mid- and long-term basis. The final message of this paper reinforces that sugarcane straw should not be considered by researchers, managers, and farmers as "waste" and/or "trash" but should be viewed as a key component to increase the sustainability of sugarcane-based products.

Acknowledgments We would like to thank LNBR technicians' group for all the support in the field and laboratory activities, and the mills for providing the experimental sites and the logistical support during the fieldwork.

Funding Information This research was financially supported by the Sugarcane Renewable Electricity project - SUCRE/PNUD (grant number BRA/10/G31) and National Council for Scientific and Technological Development-CNPq (grant 406922/2013-6). ROB and MRC are grateful to the Sao Paulo Research Foundation - FAPESP for providing the research grants (no. 2017/23978-7 and no. 2018/09845-7). ST thanks the Brazilian Federal Agency for Support and Evaluation of Graduate Education - (CAPES/CNPEM program) for providing her doctoral fellowship (grant 88882.143503/2017-01).

\section{Compliance with Ethical Standards}

Conflict of Interest The authors declare that they have no conflict of interest.

Open Access This article is distributed under the terms of the Creative Commons Attribution 4.0 International License (http:// creativecommons.org/licenses/by/4.0/), which permits unrestricted use, distribution, and reproduction in any medium, provided you give appropriate credit to the original author(s) and the source, provide a link to the Creative Commons license, and indicate if changes were made.

\section{References}

1. Food and Agriculture Organization of the United Nations - FAO (2017) FAOSTAT - Production - Crops: sugarcane. http://www. fao.org/faostat/en/\#data/QC. Accessed 20 Feb 2019

2. Companhia Nacional de Abastecimento - Conab (2019) Série histórica das safras - Cana-de-açúcar. https://www.conab.gov.br/ info-agro/safras/serie-historica-das-safras. Accessed 20 Feb 2019

3. Sindicato Nacional da Indústria de Componentes para Veículos Automotores - SINDIPEÇAS / Associação Brasileira da Indústria de Autopeças - ABIPEÇAS (2018) Relatório da Frota Circulante 2018. http://automotivebusiness.com.br/abinteligencia/pdf/R_ Frota_Circulante_2018.pdf. Accessed 21 Feb 2019
4. Dias HB, Sentelhas PC (2018) Sugarcane yield gap analysis in Brazil - a multi-model approach for determining magnitudes and causes. Sci Total Environ 637-638:1127-1136. https://doi.org/10. 1016/j.scitotenv.2018.05.017

5. Lisboa IP, Cherubin MR, Lima RP, Cerri CC, Satiro LS, Wienhold BJ, Schmer MR, Jin VL, Cerri CEP (2018) Sugarcane straw removal effects on plant growth and stalk yield. Ind Crop Prod 111:794 806. https://doi.org/10.1016/j.indcrop.2017.11.049

6. Bordonal RO, Carvalho JLN, Lal R, Figueiredo EB, de Oliveira BG, La Scala N (2018a) Sustainability of sugarcane production in Brazil. A review. Agron Sustain Dev 38:13. https://doi.org/10. 1007/s13593-018-0490-x

7. Ministério de Minas e Energia - MME, Brasil (2018) RENOVABIO program. http://www.mme.gov.br/web/guest/ secretarias/petroleo-gas-natural-e-combustiveis-renovaveis/ programas/renovabio/principal. Accessed 21 Feb 2019

8. Carvalho JLN, Nogueirol RC, Menandro LMS, Bordonal RO, Borges CD, Cantarella H, Franco HCJ (2017a) Agronomic and environmental implications of sugarcane straw removal: a major review. Global Change Biol Bioenergy 9:1181-1195. https://doi. org $/ 10.1111 / \mathrm{gcbb} .12410$

9. Companhia Nacional de Abastecimento - Conab (2018) Acompanhamento de safra brasileira de cana-de-açúcar. v. 5 Safra 2018/2019, n 3 - Terceiro Levantamento, Brasília. https://www.conab.gov.br/info-agro/safras/cana. Accessed 20 Feb 2019

10. Khatiwada D, Leduc S, Silveira S, McCallum I (2016) Optimizing ethanol and bioelectricity production in sugarcane biorefineries in Brazil. Renew Energy 85:371-386

11. Cherubin MR, Oliveira DMS, Feigl BJ, Pimentel LG, Lisboa IP, Gmach MR, Varanda LL, Moraes MC, Satiro LS, Popin GV, Paiva SR, Santos AKB, Vasconcelos ALS, Melo PLA, Cerri CEP, Cerri CC (2018) Crop residue harvest for bioenergy production and its environmental implications: a review. Sci Agric 75:255-272. https://doi.org/10.1590/1678-992x-2016-0459

12. Bordonal RO, Menandro LMS, Barbosa LC, Lal R, Milori DMBP, Kolln OT, Franco HCJ, Carvalho JLN (2018b) Sugarcane yield and soil carbon response to straw removal in south-central Brazil. Geoderma 328:79-90. https://doi.org/10.1016/j.geoderma.2018. 05.003

13. Lisboa IP, Cherubin MR, Satiro LS, Siquera-Neto M, Lima RP, Gmach MR, Wienhold BJ, Schmer MR, Jin VL, Cerri CC, Cerri CEP (2019) Applying Soil Management Assessment Framework (SMAF) on short-term sugarcane straw removal in Brazil. Ind Crop Prod 129:175-184. https://doi.org/10.1016/j. indcrop.2018.12.004

14. de Oliveira MA, Zucareli C, Neves CSVJ, Domingues AR, de Conti Medina C, de Assis Moraes LA (2016) Agronomic performance of sugarcane cultivated under quantities of sugarcane straw on the soil surface. Semina: Ciên Agrár 37:3983-3996. https://doi. org/10.5433/1679-0359.2016v37n6p3983

15. de Aquino GS, Medina CC, da Costa DC, Shahab M, Santiago AD (2017) Sugarcane straw management and its impact on production and development of ratoons. Ind Crop Prod 102:58-64. https://doi. org/10.1016/j.indcrop.2017.03.018

16. Thornthwaite CW (1948) An approach toward a rational classification of climate. Geogr Rev 38:55-94

17. Popin GV (2017) Effect of sugarcane straw management on soilplant relations in Igaraçu do Tietê-SP. Dissertation (master on soils and plant nutrition). Luiz de Queiroz College of Agriculture. Univ of São Paulo, Piracicaba

18. Zotelli LC (2012) Trash and vinasse: emissions of $\mathrm{CO}_{2}, \mathrm{~N}_{2} \mathrm{O}$ and $\mathrm{CH}_{4}$ from soil with sugarcane. Dissertation (master on tropical and subtropical agriculture). Instituto Agronômico, Campinas

19. Rossetto R, Vitti AC, Gava GJC, Mellis EV, Vargas VP, Cantarella H, Prado H, Dias FLF, Landell MGA, Brancalião SR, Garcia JC 
(2013) Cana-de-açúcar - cultivo com sustentabilidade. Informações agronômicas 142:1-13

20. Van Raij B, Andrade JC, Cantarella H, Quaggio JA (2001) Análise Química para Avaliação da Fertilidade de Solos Tropicais. Instituto Agronômico, Campinas

21. Blake GR, Hartge KH (1986) Bulk density. In: Klute A (ed) Methods of soil analysis. Part 1. Physical and mineralogical methods, 2nd edn. American Society of Agronomy, WI, USA, Madison, pp 363-375

22. Castioni GA, Cherubin MR, Menandro LMS, Sanches GM, de Oliveira Bordonal R, Barbosa LC, Franco HCJ, Carvalho JLN (2018) Soil physical quality response to sugarcane straw removal in Brazil: a multi-approach assessment. Soil Tillage Res 184:301309. https://doi.org/10.1016/j.still.2018.08.007

23. R Development Core Team (2015) R: a language and environment for statistical computing. R Foundation for Statistical Computing, Vienna, Austria. http://www.R-project.org/. Accessed 20 Sep 2018

24. Menandro LMS, Cantarella H, Franco HCJ, Kölln OT, Pimenta MTB, Sanches GM, Rabelo SC, Carvalho JLN (2017) Comprehensive assessment of sugarcane straw: implications for biomass and bioenergy production. Biofuels Bioprod Biorefin 11: 488-504. https://doi.org/10.1002/bbb.1760

25. Fortes C, Trivelin PCO, Vitti AC (2012) Long-term decomposition of sugarcane harvest residues in Sao Paulo state, Brazil. Biomass Bioenergy 42:189-198. https://doi.org/10.1016/j.biombioe.2012. 03.011

26. Martins Filho MV, Liccioti TT, Pereira GT, Marques Junior J, Sanches RB (2009) Perdas de solo e nutrientes por erosão num argissolo com resíduos vegetais de cana-de-açúcar. Engenharia Agrícola 29:8-18

27. Gmach MR, Scarpare FV, Cherubin MR, Lisboa IP, Santos AKB, Cerri CEP, Cerri CC (2019) Sugarcane straw removal effects on soil water storage and drainage in Southeastern Brazil. J Soil Water Conserv (in press)

28. Cerri CC, Bernoux M, Feller C, Campos DC, De Luca EF, Eschenbrenner V (2004) Cannea Sucre et Sequestration du Carbone. Academie d'Agriculture de France 17:1-15

29. Gonzaga LC, Carvalho JLN, de Oliveira BG, Soares JR, Cantarella $511 \mathrm{H} \mathrm{(2018)}$ Crop residue removal and nitrification inhibitor application as strategies to mitigate $\mathrm{N}_{2} \mathrm{O}$ emissions in sugarcane fields. Biomass Bioenergy 119:206-216. https://doi.org/10.1016/j. biombioe.2018.09.015

30. Arrigoni EB (2011) New pests of the new system. Revista Opiniões 28:65-67

31. Awe GO, Reichert JM, Wendroth OO (2015) Temporal variability and covariance structures of soil temperature in a sugarcane field under different management practices in southern Brazil. Soil Tillage Res 150:93-106. https://doi.org/10.1016/j.still.2015.01.013

32. Alvares CA, Stape JL, Sentelhas PC, De Moraes Gonçalves JL, Sparovek G (2013) Köppen's climate classification map for Brazil. Meteorol Z 22:711-728. https://doi.org/10.1127/09412948/2013/0507

33. Marin F, Thorburn P, Costa LG, Otto R (2014) Simulating longterm effects of trash management on sugarcane yield for Brazilian cropping systems. Sugar Tech 16:164-173. https://doi.org/10.1007/ s12355-013-0265-2

34. Monteiro LA, Sentelhas PC (2017) Sugarcane yield gap: can it be determined at national level with a simple agrometeorologicalmodel? Crop Pasture Sci 68:272-284. https:// doi.org/10.1071/CP16334

35. Satiro LS, Cherubin MR, Lisboa IP, de Souza Noia Junior R, Cerri CC, Cerri CEP (2019) Prediction of sugarcane yield by soil attributes under straw removal management. Agron J 110:1-10. https:// doi.org/10.2134/agronj2018.01.0021
36. Garside AL, Bell MJ, Robotham BG, Magarey RC, Stirling GR (2005) Managing yield decline in sugarcane cropping systems. Int Sugar J 107:16-26

37. Jones MR, Singels A (2015) Analyzing yield trends in the South African sugar industry. Agric Syst 141:24-35. https://doi.org/10. 1016/j.agsy.2015.09.004

38. Franco HCJ, Castro SGQ, Sanches GM, Kolln OT, Bordonal RO, Borges BMMN, Borges CD (2017) Chapter 15 Alternatives to increase the sustainability of sugarcane production in Brazil under high intensive mechanization. In: Singh, P.; Tiwari, A.K. Sustainable sugarcane production. Apple Academic Press 426p

39. Marin FR, Pellegrino GQ, Assad ED, Pinto HS, Zullo Junior F (2009) Cana-de-açúcar. In: Monteiro, JEBA (Ed) agrometeorologia dos cultivos: o fator meteorológico na produção agrícola. Brasília: INMET, p.111-130

40. Thomashow, 2010 Singh S. (1988) Effect of temperature on germination of sugar cane seeds (fluff). Sugarcane 1:11-12

41. Cardozo NP, Bordonal RO, La Scala N (2018) Sustainable intensification of sugarcane production under irrigation systems, considering climate interactions and agricultural efficiency. J Clean Prod 204:861-871. https://doi.org/10.1016/j.jclepro. 2018.09.004

42. Barbosa LC, de SZM, Franco HCJ et al (2018) Soil texture affects root penetration in Oxisols under sugarcane in Brazil. Geoderma Reg 13:15-25. https://doi.org/10.1016/j.geodrs.2018.03.002

43. Tenelli S, Bordonal RO, Barbosa LC, Carvalho JLN (2019) Can reduced tillage sustain sugarcane yield and soil carbon if straw is removed? BioEnergy Res. https://doi.org/10.1007/s12155-01909996-3

44. Corrêa STR, Barbosa LC, Menandro LMS, Scarpare FV, Reichardt K, Moraes LO, Hernandes TAD, Franco HCJ, Carvalho JLN (2019) Straw removal effects on soil water dynamics, soil temperature, and sugarcane yield in South-central Brazil. BioEnergy Res. https://doi. org/10.1007/s12155-019-09981-w

45. Fontes MPF, Alleoni LRF (2006) Electrochemical attributes and availability of nutrients, toxic elements, and heavy metals in tropical soils. Sci Agric 63:589-608. https://doi.org/10.1590/S010390162006000600014

46. Campos LHF, Carvalho SJP, Christoffoleti PJ, Fortes C, Silva JS (2010) Sistemas de manejo da palhada influenciam acúmulo de biomassa e produtividade da cana-de-açúcar (var. RB855453). Acta Sci Agron 32:345-350. https://doi.org/10.4025/actasciagron. v32i2.3703

47. Carvalho JLN, Hudiburg TW, Franco HCJ, DeLucia EH (2017b) Contribution of above- and belowground bioenergy crop residues to soil carbon. Global Change Biol Bioenergy 9:1333-1343. https:// doi.org/10.1111/gcbb. 12411

48. Cherubin MR, Karlen DL, Franco ALC, Tormena CA, Cerri CEP, Davies CA, Cerri CC (2016) Soil physical quality response to sugarcane expansion in Brazil. Geoderma 267:156-168. https://doi. org/10.1016/j.geoderma.2016.01.004

49. Trivelin PCO, Franco HCJ, Otto R, Ferreira DA, Vitti AC, Fortes C, Faroni CE, Oliveira ECA, Cantarella H (2013) Impact of sugarcane trash on fertilizer requirements for São Paulo, Brazil. Sci Agric 70: 345-352. https://doi.org/10.1590/S0103-90162013000500009

50. Dinardo-Miranda LL, Fracasso JV (2013) Sugarcane straw and the populations of pests and nematodes. Sci Agric 70:305-310. https:// doi.org/10.1590/S0103-90162013000500012

51. Rossi Neto J, de Souza ZM, Kölln OT, Carvalho JLN, Ferreira DA, Castioni GAF, Barbosa LC, de Castro SGQ, Braunbeck OA, Garside AL, Franco HCJ (2018) The arrangement and spacing of sugarcane planting influence root distribution and crop yield. BioEnergy Res 11:291-304. https://doi.org/10.1007/s12155-0189896-1 
52. Castro SGQ, Magalhães PSG, Franco HCJ, Mutton MA (2018) Harvesting systems, soil cultivation, and nitrogen rate associated with sugarcane yield. BioEnergy Res 11:583-591. https://doi.org/ 10.1007/s12155-018-9917-0

53. Leal MRL, Galdos MV, Scarpare FV, Seabra JE, Walter A, Oliveira CO (2013) Sugarcane straw availability, quality, recovery and energy use: a literature review. Biomass Bioenergy 53:11-19. https://doi.org/10.1016/j.biombioe.2013.03.007

Publisher's Note Springer Nature remains neutral with regard to jurisdictional claims in published maps and institutional affiliations. 